University of Wollongong

Research Online

Faculty of Engineering and Information

Faculty of Engineering and Information

Sciences - Papers: Part A

Sciences

$1-1-2013$

Trace elements in the si furnace-part II: analysis of condensate in carbothermal reduction of quartz

\author{
Elena Dal Martello \\ NTNU, Trondheim, Norway \\ Gabriella Tranell \\ NTNU, Trondheim, Norway \\ Oleg Ostrovski \\ University of New South Wales \\ Guangqing Zhang \\ University of Wollongong, gzhang@uow.edu.au \\ Ola Raaness \\ SINTEF, Trondheim, Norway
}

See next page for additional authors

Follow this and additional works at: https://ro.uow.edu.au/eispapers

Part of the Engineering Commons, and the Science and Technology Studies Commons

Research Online is the open access institutional repository for the University of Wollongong. For further information contact the UOW Library: research-pubs@uow.edu.au 


\title{
Trace elements in the si furnace-part II: analysis of condensate in carbothermal reduction of quartz
}

\begin{abstract}
Silicon feedstock for production of solar-grade silicon should be as pure as possible to decrease the cost of manufacturing of solar cells. Impurities in quartz, carbonaceous materials, electrodes, and refractories are mostly present in the form of oxides. These oxides can be reduced to volatile gaseous compounds in presence of $\mathrm{SiO}(\mathrm{g})$ and $\mathrm{CO}(\mathrm{g})$ atmosphere and potentially leave the furnace or stay in the condensed reaction products, metal, and slag. This work investigates the conditions under which volatile impurities report to the gas phase in laboratory experiments with lumpy and pelletized mixtures of $\mathrm{SiO} 2, \mathrm{SiC}$, and $\mathrm{Si}$ at $1923 \mathrm{~K}$ and $2123 \mathrm{~K}\left(1650^{\circ} \mathrm{C}\right.$ and $\left.1850^{\circ} \mathrm{C}\right)$, respectively, were carried out. The volatile compounds were generated by the reduction of quartz and collected in the form of condensate. The effects of the reaction temperature, quartz type, charge composition, pellets, and lumps on the composition of the condensate were studied. The trace elements in the charge input, reacting charge, and condensate were analyzed using inductively coupled plasma (ICP)-mass spectroscopy (MS) and X-ray diffraction (XRD). CO(g) and $\mathrm{SiO}(\mathrm{g})$, which are the major components in reduction reactions, formed four types of condensate: white, brown, green, and orange. The condensate constituents were amorphous $\mathrm{SiO} 2,3 \mathrm{C}$ :SiC, Si, and $\alpha$-quartz. Each impurity present in the quartz charge entered the gas phase during quartz reduction and was detected in the condensate. Al and Fe show limited volatility. The volatility of Mn, P, and B depends on the charge mix: a higher PCO enhances the concentration of these elements in the gas phase. Fluid inclusions, common in hydrothermal quartz, enhance the distribution of the contaminants to the gas phase. Industrial campaigns on Si and Fe-Si production confirm the experimental results.
\end{abstract}

\section{Keywords}

carbothermal, condensate, analysis, quartz, ii, trace, part, reduction, furnace, si, elements

\section{Disciplines}

Engineering | Science and Technology Studies

\section{Publication Details}

Martello, E. Dal., Tranell, G., Ostrovski, O., Zhang, G., Raaness, O., Larsen, R. Berg., Tang, K. \& Koshy, P. (2013). Trace elements in the si furnace-part II: analysis of condensate in carbothermal reduction of quartz. Metallurgical and Materials Transactions B: Process Metallurgy and Materials Processing Science, 44 (2), 244-251.

\section{Authors}

Elena Dal Martello, Gabriella Tranell, Oleg Ostrovski, Guangqing Zhang, Ola Raaness, Rune Berg Larsen, Kai Tang, and Pramod Koshy 


\title{
Trace Elements in the Si Furnace-Part II: Analysis of Condensate in Carbothermal Reduction of Quartz
}

\author{
ELENA DAL MARTELLO, GABRIELLA TRANELL, OLEG OSTROVSKI, \\ GUANGQING ZHANG, OLA RAANESS, RUNE BERG LARSEN, \\ KAI TANG, and PRAMOD KOSHY
}

\begin{abstract}
Silicon feedstock for production of solar-grade silicon should be as pure as possible to decrease the cost of manufacturing of solar cells. Impurities in quartz, carbonaceous materials, electrodes, and refractories are mostly present in the form of oxides. These oxides can be reduced to volatile gaseous compounds in presence of $\mathrm{SiO}(\mathrm{g})$ and $\mathrm{CO}(\mathrm{g})$ atmosphere and potentially leave the furnace or stay in the condensed reaction products, metal, and slag. This work investigates the conditions under which volatile impurities report to the gas phase in laboratory experiments with lumpy and pelletized mixtures of $\mathrm{SiO}_{2}, \mathrm{SiC}$, and $\mathrm{Si}$ at $1923 \mathrm{~K}$ and $2123 \mathrm{~K}\left(1650{ }^{\circ} \mathrm{C}\right.$ and $1850^{\circ} \mathrm{C}$ ), respectively, were carried out. The volatile compounds were generated by the reduction of quartz and collected in the form of condensate. The effects of the reaction temperature, quartz type, charge composition, pellets, and lumps on the composition of the condensate were studied. The trace elements in the charge input, reacting charge, and condensate were analyzed using inductively coupled plasma (ICP)-mass spectroscopy (MS) and X-ray diffraction $(\mathrm{XRD}) . \mathrm{CO}(\mathrm{g})$ and $\mathrm{SiO}(\mathrm{g})$, which are the major components in reduction reactions, formed four types of condensate: white, brown, green, and orange. The condensate constituents were amorphous $\mathrm{SiO}_{2}, 3 \mathrm{C}: \mathrm{SiC}, \mathrm{Si}$, and $\alpha$-quartz. Each impurity present in the quartz charge entered the gas phase during quartz reduction and was detected in the condensate. $\mathrm{Al}$ and $\mathrm{Fe}$ show limited volatility. The volatility of $\mathrm{Mn}, \mathrm{P}$, and $\mathrm{B}$ depends on the charge mix: a higher $\mathrm{P}_{\mathrm{CO}}$ enhances the concentration of these elements in the gas phase. Fluid inclusions, common in hydrothermal quartz, enhance the distribution of the contaminants to the gas phase. Industrial campaigns on $\mathrm{Si}$ and $\mathrm{Fe}-\mathrm{Si}$ production confirm the experimental results.
\end{abstract}

DOI: $10.1007 / \mathrm{s} 11663-012-9720-9$

(C) The Minerals, Metals \& Materials Society and ASM International 2012

\section{INTRODUCTION}

REDUCING agents in carbothermal reduction of silica include carbon (coke and/or char), $\mathrm{SiO}(\mathrm{g}), \mathrm{CO}(\mathrm{g})$, and $\mathrm{SiC}$. In the process of silica reduction, impurity oxides present in the charge material are also reduced. Less stable oxides than silica, such as oxides of $\mathrm{Ni}, \mathrm{Co}$, $\mathrm{Fe}, \mathrm{Pb}, \mathrm{Cu}, \mathrm{Cr}, \mathrm{Mn}, \mathrm{Zn}, \mathrm{Na}$, and $\mathrm{K}$ are easily reduced and partitioned between silicon, oxide, and gas phases, while stable oxides of $\mathrm{Ca}, \mathrm{Al}, \mathrm{Ti}$, and $\mathrm{Mg}$ are not reduced. The reduced species can be removed from quartz in the form of volatile gaseous phases. Gaseous species comprise pure metals, as well as suboxides and

ELENA DAL MARTELLO, Ph.D., and GABRIELLA TRANELL, Professor, are with the Department of Materials Science and Engineering, NTNU, Trondheim, Norway. Contact e-mails: dalmarte@material.ntnu.no; dalmarte@yahoo.it.OLEG OSTROVSKI, Professor, and PRAMOD KOSHY, Research Associate, are with UNSW Materials Science and Engineering, Sydney, NSW, Australia. GUANGQING ZHANG, Lecturer, is with UOW, Wollongong, NSW, Australia. OLA RAANESS, Senior Advisor, and KAI TANG, Research Scientist, are with SINTEF Materials and Chemistry, Trondheim, Norway. RUNE BERG LARSEN, Professor, is with the Department of Geology and Mineral Resources Engineering, NTNU, Trondheim, Norway.

Manuscript submitted June 15, 2012.

Article published online September 27, 2012. combination of metal oxides and hydroxides. The partial pressure of the gaseous species depends on the activities of elements in raw materials and reaction temperature.

Myrhaug and Tveit studied the distribution of trace elements present in the metal, "microsilica" (condensed silica fume) and off gases for a Fe-Si furnace ${ }^{[1]}$ and $\mathrm{Si}$ furnace. ${ }^{[2,3]}$ The trace elements found in the microsilica were mainly $\mathrm{K}, \mathrm{Zn}, \mathrm{Na}, \mathrm{Mg}$, and $\mathrm{Pb}$, whereas the elements found in the $\mathrm{Fe}-\mathrm{Si}$ alloy were primarily $\mathrm{Cu}, \mathrm{Cr}$, $\mathrm{P}, \mathrm{Mn}, \mathrm{Al}, \mathrm{Cr}, \mathrm{Ni}, \mathrm{Fe}, \mathrm{B}$, and Ti. The behavior of $\mathrm{P}$ is dependent on the $\mathrm{Fe}$ content in the charge: In the $\mathrm{Si}$ furnace, 85 pct of $\mathrm{P}$ input reports to microsilica, while in the Fe-Si furnace, only 25 pct. Myrhaug ${ }^{[4]}$ described the behavior of trace elements in the silicon furnace with a model based on the boiling temperature of pure elements. The model assumes that an element evaporates when its boiling point is lower than the process temperature. The boiling point model refers to the case of partial pressure of the elements over the pure element $P_{E L}^{0}$ equals $1 \mathrm{~atm}$, when activity of the elements $a_{E L}$ equals to 1 , which is not representative of the real case. Moreover, the model does not take into account the fact that gaseous compounds other than the pure elements may form. Impurities found in the microsilica and in the off gases do not necessarily represent the total amount 
of gaseous compounds formed in the furnace: Gaseous compounds may condense and circulate in the furnace, which is a process known in the manganese production $\left(\mathrm{Zn}(\mathrm{g})\right.$ and $\mathrm{K}(\mathrm{g})$ react with $\mathrm{CO}(\mathrm{g})$ and $\mathrm{CO}_{2}(\mathrm{~g})$ forming $\mathrm{ZnO}(\mathrm{s})$ and $\mathrm{K}_{2} \mathrm{CO}_{3}(1, \mathrm{~s})$, respectively ${ }^{[5-7]}$ ).

The formation of gaseous species is concurrent and linked with the production of $\mathrm{SiO}(\mathrm{g})$ and $\mathrm{CO}(\mathrm{g})$ in an industrial reduction furnace. The main reactions leading to the formation of $\mathrm{SiO}(\mathrm{g})$ and $\mathrm{CO}(\mathrm{g})$ are shown by Eqs. [1] and [2] at $1873 \mathrm{~K}\left(1600{ }^{\circ} \mathrm{C}\right)$ and by Eqs. [3] through [5] at higher temperatures. In particular, $\mathrm{SiO}(\mathrm{g})$ is formed at the $\mathrm{SiO}_{2}, \mathrm{SiC}$, and $\mathrm{Si}$ surfaces, while $\mathrm{CO}(\mathrm{g})$ is formed at the $\mathrm{C}$ and $\mathrm{SiC}$ surfaces. ${ }^{[8]}$

The main condensation reactions occurring in the system are given by Eqs. [6] through [9]. The reaction [6] is found to occur in the temperature range of $1873 \mathrm{~K}$ to $1973 \mathrm{~K}\left(1600{ }^{\circ} \mathrm{C}\right.$ to $\left.1700^{\circ} \mathrm{C}\right) \cdot{ }^{[9,10]}$ The reactions [7] and [9] occur at temperatures lower than $1773 \mathrm{~K}$ $\left(1500^{\circ} \mathrm{C}\right) .^{[8,11,12]}$ The reaction [6] produces a brown condensate, ${ }^{[9,10,13]}$ reaction [7] produces a white condensate, while reaction [8] produces a green condensate. ${ }^{[12]}$ Andersen et al. and Vangskåsen ${ }^{[10,13]}$ showed that the brown condensate consists of silicon spheres ranging in size from 100 to $1000 \mathrm{~nm}$ in a matrix of $\mathrm{SiO}_{2}$.

$$
\begin{gathered}
\mathrm{SiO}_{2(\mathrm{~s}, \mathrm{l})}+\mathrm{C}_{(\mathrm{s})}=\mathrm{SiO}_{(\mathrm{g})}+\mathrm{CO}_{(\mathrm{g})} \\
\mathrm{SiO}_{(\mathrm{g})}+2 \mathrm{C}_{(\mathrm{s})}=\mathrm{SiC}_{(\mathrm{s})}+\mathrm{CO}_{(\mathrm{g})} \\
2 \mathrm{SiO}_{2(\mathrm{~s}, \mathrm{l})}+\mathrm{SiC}_{(\mathrm{s})}=3 \mathrm{SiO}_{(\mathrm{g})}+\mathrm{CO}_{(\mathrm{g})} \\
\mathrm{SiO}_{(\mathrm{g})}+\mathrm{SiC}_{(\mathrm{s})}=2 \mathrm{Si}_{(\mathrm{l})}+\mathrm{CO}_{(\mathrm{g})} \\
\mathrm{SiO}_{2(\mathrm{l})}+\mathrm{Si}_{(\mathrm{l})}=2 \mathrm{SiO}_{(\mathrm{g})} \\
2 \mathrm{SiO}_{(\mathrm{g})}=\mathrm{SiO}_{2(\mathrm{~S})}+\mathrm{Si}_{(\mathrm{s})} \\
3 \mathrm{Si}_{(\mathrm{l})}+2 \mathrm{CO}_{(\mathrm{g})}=2 \mathrm{SiC}_{(\mathrm{s})}+\mathrm{SiO}_{(\mathrm{s})} \\
2 \mathrm{Si}_{(\mathrm{l})}+\mathrm{CO}_{(\mathrm{g})}=\mathrm{SiC}_{(\mathrm{s})}+\mathrm{SiO}_{(\mathrm{g})} \\
3 \mathrm{SiO}_{(\mathrm{g})}+\mathrm{CO}_{(\mathrm{g})}=2 \mathrm{SiO}_{2(\mathrm{~s})}+\mathrm{SiC}_{(\mathrm{s})}
\end{gathered}
$$

This article, which is the second of a series of two (see Reference 14), investigates the behavior of the impurities in quartz when quartz is heated in reducing atmosphere. The major focus is on the impurities that leave the quartz during reduction and enter the gas phase.

\section{ANALYSIS OF CONDENSATE AND THERMODYNAMIC SIMULATION}

The experimental matrix, equipment, and procedures were described elsewhere. ${ }^{[14]}$ The gaseous compounds formed during the experiments were collected in a form of condensate on the inner surface of the graphite

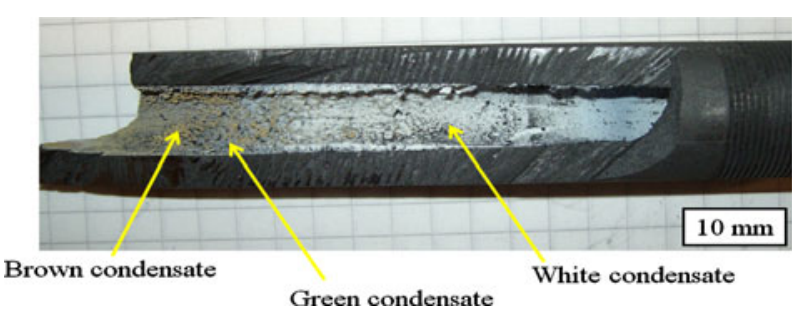

Fig. 1-Appearance of the condensates collected in the graphite tube [experimental condition "pellets $\mathrm{SiO}_{2}+\mathrm{SiC} 1923 \mathrm{~K}\left(1650^{\circ} \mathrm{C}\right)$ "] Three types of condensate (white, brown, and green) are sticking in the first $6 \mathrm{~cm}$ of the tube.

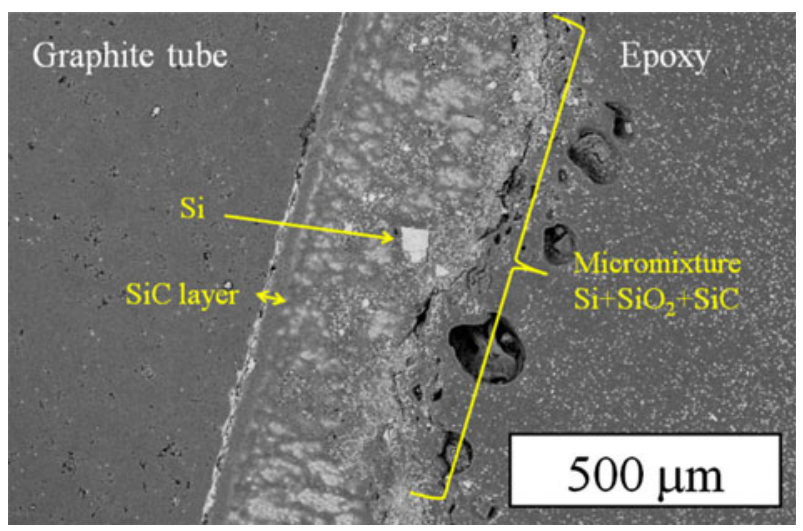

Fig. 2-Backscattering image of a mixture of white and brown condensate collected in a graphite tube. The condensate has reacted actively with the graphite tube forming a thin $\mathrm{SiC}$ layer, which is the region containing the two white lines.

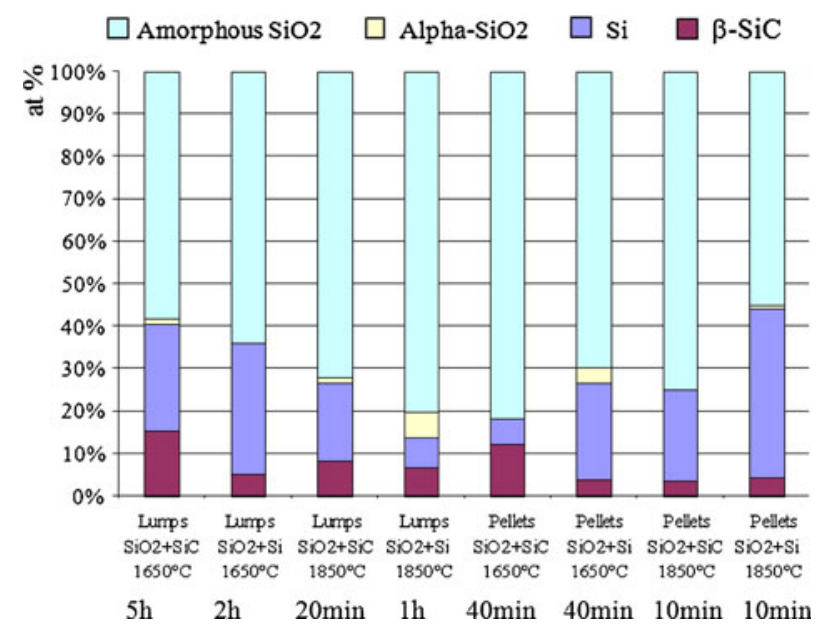

Fig. 3 - Condensate composition (at. pct) under eight different experimental conditions. The time required for the condensate to block the tube is shown below the graphs.

ducting tube. The different condensate phases were recovered from the inner surface of the tube using a tungsten carbide tool, mixed, and collected in one sample. The sample was crushed with an agate mortar of 99.91 pet to the microns size needed for the analysis.

Two analytical methods were used for the analysis of the condensate samples: inductively coupled plasma (ICP)-mass spectrometry (MS) and X-ray diffraction 


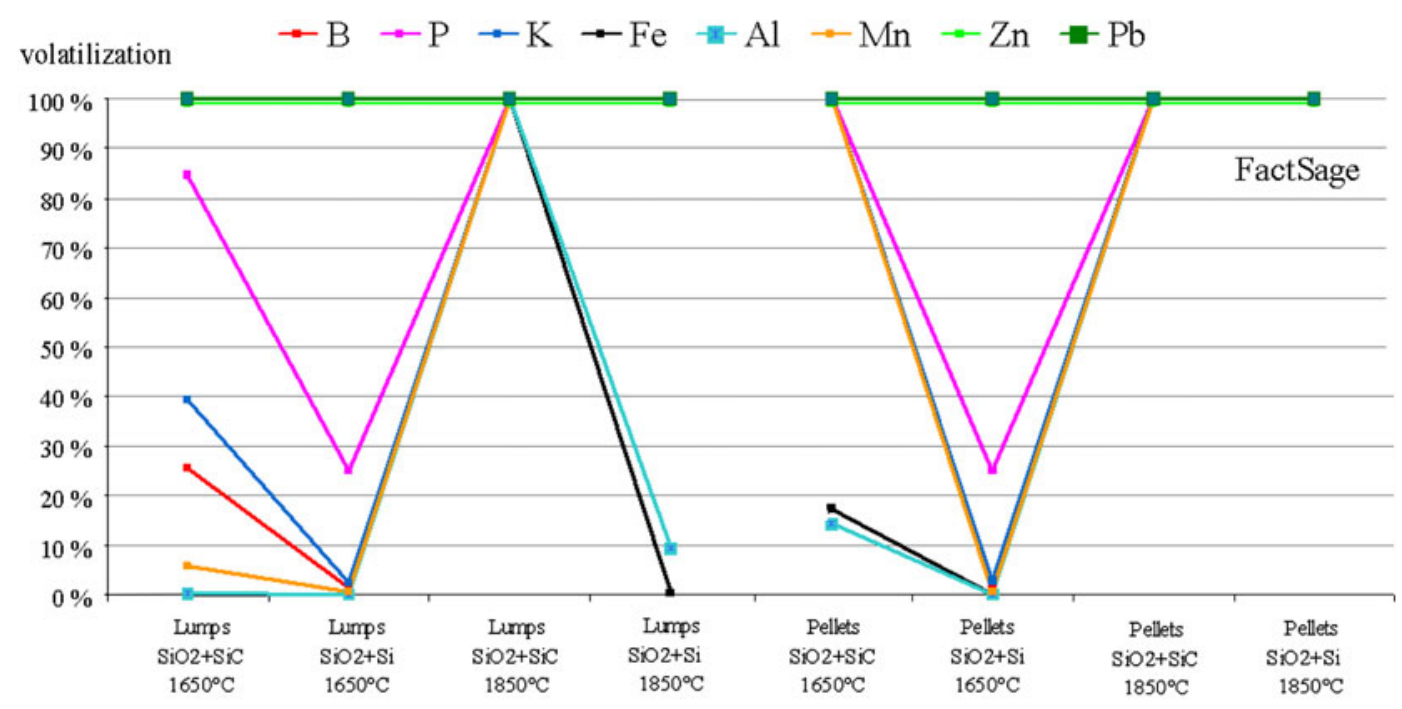

volatilization

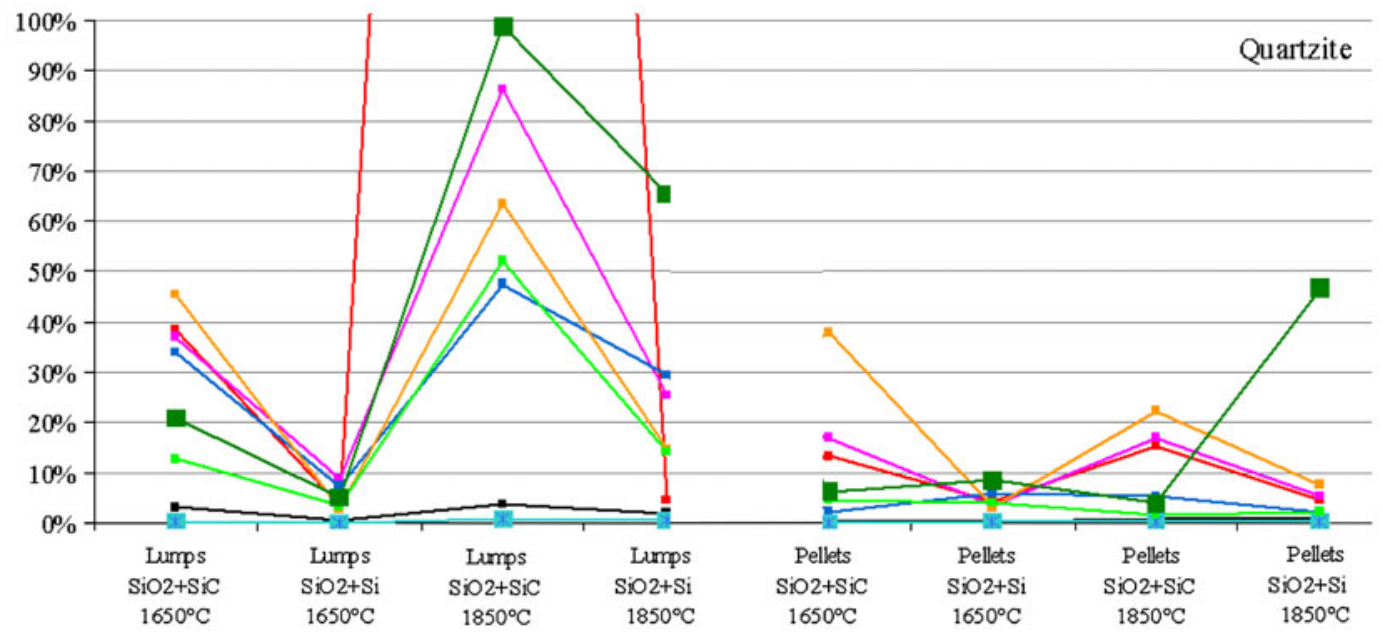

volatilization

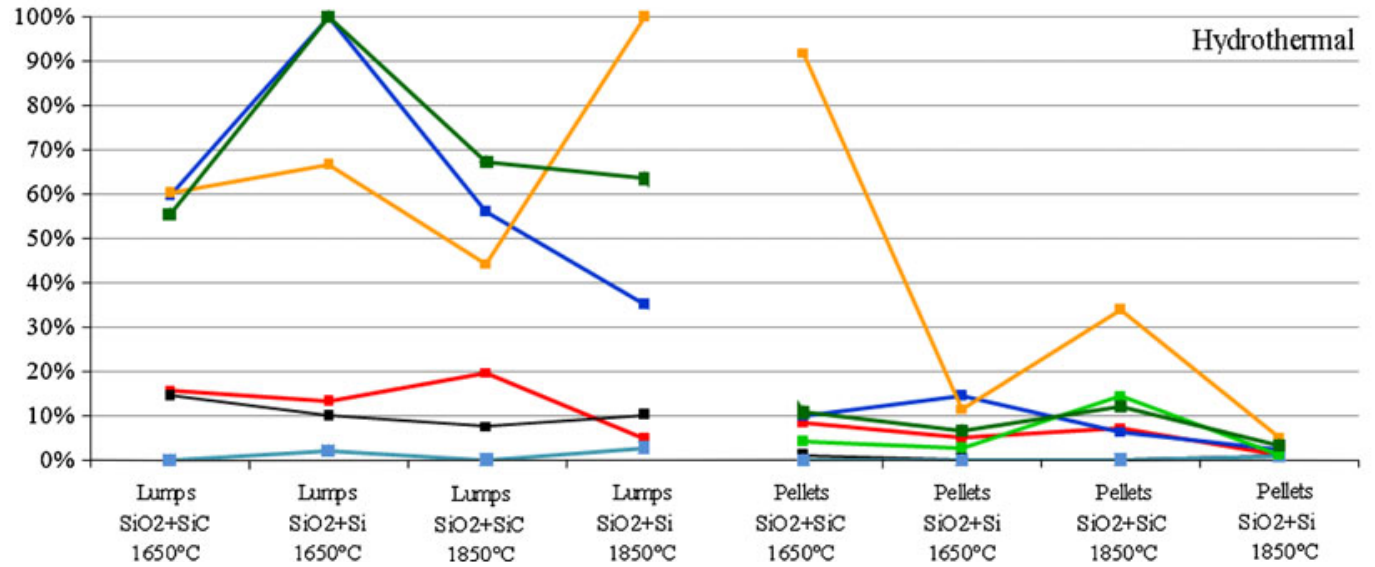

Fig. 4-Volatilization of elements in mass pet shown for different charge types, mixes and temperatures. Top to bottom: thermodynamic calculations, quartzite, and hydrothermal quartz. The volatility of $\mathrm{P}$ and $\mathrm{Zn}$ are not shown for all the experimental conditions in hydrothermal quartz because of the high concentration of these elements in the blank used as analytical reference. 


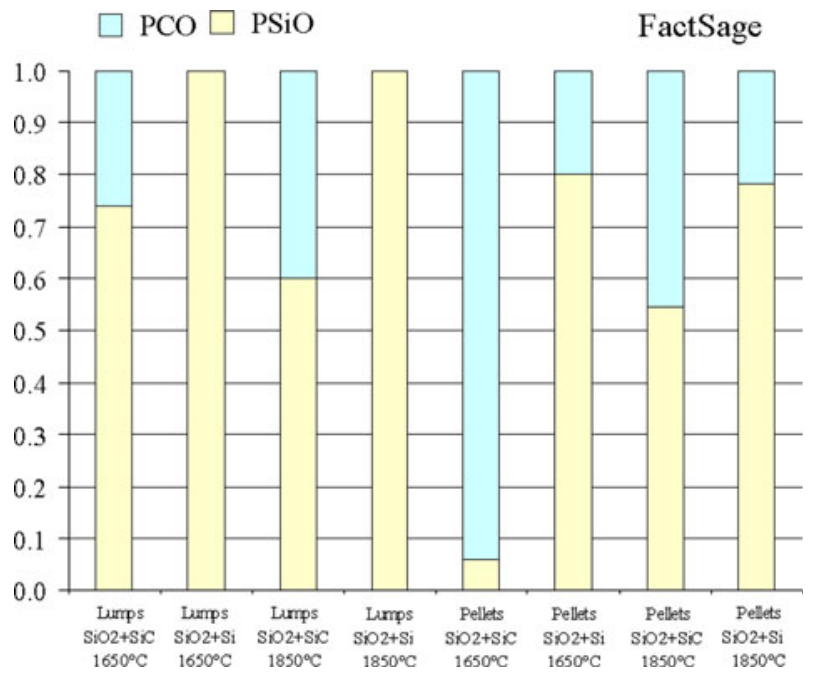

Fig. 5-Partial pressure $\mathrm{P}_{\mathrm{CO}}$ and $\mathrm{P}_{\mathrm{SiO}}$ formed at equilibrium conditions calculated with FactSage.

(XRD). The content of the impurity trace elements in the condensate was detected by ICP-MS. Details on the ICPMS analysis are given in Reference 14. XRD was used to identify and quantify the phases present in the condensate. For the phase quantification, the Rietveld method was used. ${ }^{[15]}$ Because the condensate contains amorphous silica, 5 wt pct $\mathrm{Al}_{2} \mathrm{O}_{3}$ was added as a measurement standard to find the quantity of glassy phases in samples. First, the contents of all the crystalline phases were calculated. Then results were recalculated (normalized) to obtain a known concentration of alumina in the sample. The glassy phase content was calculated as the difference between the amount of crystalline phases and the total mass of the sample. This is a useful method to quantify amorphous phases with XRD; its disadvantage is that it is reliable only if the content of amorphous (glassy) phase is greater than $10 \mathrm{wt}$ pct.

An electron probe microanalyzer (EPMA) was used to study the morphology of the condensate.

The formation of gas compounds at equilibrium conditions was simulated using the FactSage software package (École Polytechnique de Montréal, Montréal, Canada), and the thermodynamic calculations were compared to the measured results. Eight experimental conditions, as described in Part I, have been simulated: "lumps $\mathrm{SiO}_{2}+\mathrm{SiC} 1923 \mathrm{~K} \quad\left(1650^{\circ} \mathrm{C}\right), "$ "lumps $\mathrm{SiO}_{2}+\mathrm{SiC} 2123 \mathrm{~K}\left(1850{ }^{\circ} \mathrm{C}\right)$," "lumps $\mathrm{SiO}_{2}+\mathrm{Si}$ $1923 \mathrm{~K} \quad\left(1650{ }^{\circ} \mathrm{C}\right), "$ "lumps $\mathrm{SiO}_{2}+\mathrm{Si} 2123 \mathrm{~K}$ $\left(1850{ }^{\circ} \mathrm{C}\right)$," "pellets $\mathrm{SiO}_{2}+\mathrm{SiC} 1923 \mathrm{~K}\left(1650{ }^{\circ} \mathrm{C}\right)$, ," "pellets $\mathrm{SiO}_{2}+\mathrm{SiC} 2123 \mathrm{~K} \quad\left(1850^{\circ} \mathrm{C}\right)$," "pellets $\mathrm{SiO}_{2}+\mathrm{Si} 1923 \mathrm{~K}\left(1650{ }^{\circ} \mathrm{C}\right)$," and "pellets $\mathrm{SiO}_{2}+\mathrm{Si}$ $2123 \mathrm{~K}\left(1850{ }^{\circ} \mathrm{C}\right)$." Although two different quartzes were used in the experiments, only quartz with higher concentration of impurities was examined. The thermodynamic calculations are based on the following assumptions:

- Reactions between input materials have reached equilibrium at $1 \mathrm{~atm}$ total pressure.

- Carbon content in the binder of the pellet is the only difference in the simulation of pellets compared to lumps.
- Impurities are present only in the quartz, and they are treated as oxides in a mechanical mixture with quartz (i.e., activity $=1$ ); the elements considered are $\mathrm{B}, \mathrm{P}$, $\mathrm{K}, \mathrm{Al}, \mathrm{Fe}, \mathrm{Mn}, \mathrm{Zn}$, and $\mathrm{Pb}$ with the same amount as in the quartzite.

- Oxides are reduced in the presence of $\mathrm{SiO}(\mathrm{g}), \mathrm{CO}(\mathrm{g})$, $\mathrm{C}$, and $\mathrm{SiC}$.

The FactSage (Version 6.3) pure substance database has been used to simulate the equilibrium. One hundred percent condensation is always assumed in the equilibrium calculations.

\section{RESULTS AND DISCUSSION}

\section{A. Condensate Description}

The gaseous compounds were collected in the form of condensate. Four different types of condensate (based on color) were identified: white, green, brown, and orange. The white, green, and brown condensates were found adhered in the lower part (first $6 \mathrm{~cm}$ ) of the tube, near the crucible, and were difficult to remove. The orange condensate was found as loose, flaky powder in the upper part of the tube and was easy to collect. While the white, brown, and green condensates were found in all the experiments, the presence of the orange condensate varied from very high amounts in some experiments to very small amounts in others. Figure 1 shows the appearance of the condensates found in the lower part of the tube. The microstructure of the condensate in Figure 1 is illustrated in Figure 2. The condensate is characterized by an assembly of tiny spherical particles (diameters $\sim 5 \mu \mathrm{m}$ ). Three main complexes were found: single $\mathrm{Si}$ particles in $\mathrm{SiO}_{2}$ matrix (50 at. pet $\mathrm{Si}$ and 50 at. pct $\mathrm{O}$ ), and mixtures of $\mathrm{Si}, \mathrm{C}$, and $\mathrm{O}$ without specific composition. The condensate has reacted with the graphite tube, forming a transitional $\mathrm{SiC}$ layer of $50 \mu \mathrm{m}$, which was found at the interface condensate tube. Mapping of the condensate for $\mathrm{Mg}, \mathrm{P}, \mathrm{Ca}, \mathrm{Fe}, \mathrm{K}$, and $\mathrm{Al}$ reveals that impurities generally are in too low concentrations to get reliable results from the EPMA. However, there is an indication that $\mathrm{Ca}$ and $\mathrm{Al}$ may partially report to the thin $\mathrm{SiC}$ layer formed on the tube surface. The $\mathrm{SiC}$ layer at the interface between the condensate and the graphite tube was difficult to remove with the WC filament and was therefore not possible to sample all of it. Between $2 \mathrm{~g}$ and $6 \mathrm{~g}$ of condensate were collected in each experiment; the exact amount varied from sample to sample.

The condensates produced when quartzite was used as the source of $\mathrm{SiO}_{2}$, were analyzed by XRD. The phases detected in the condensate were: amorphous $\mathrm{SiO}_{2}$, $\alpha-\mathrm{SiO}_{2}, \mathrm{Si}$, and $\beta: \mathrm{SiC}$ (products of reactions [2], and [6] through [9]). It should be noted that XRD quantitative analysis of a system with a high amount of glassy (amorphous) phase can only be semiquantitative. However, the relative proportions of the crystalline phases are considered accurate. The condensate composition (in mole percent) for the eight experimental conditions and the time required for the condensate to block the tube are shown in Figure 3. Crystalline quartz, amorphous silica, 

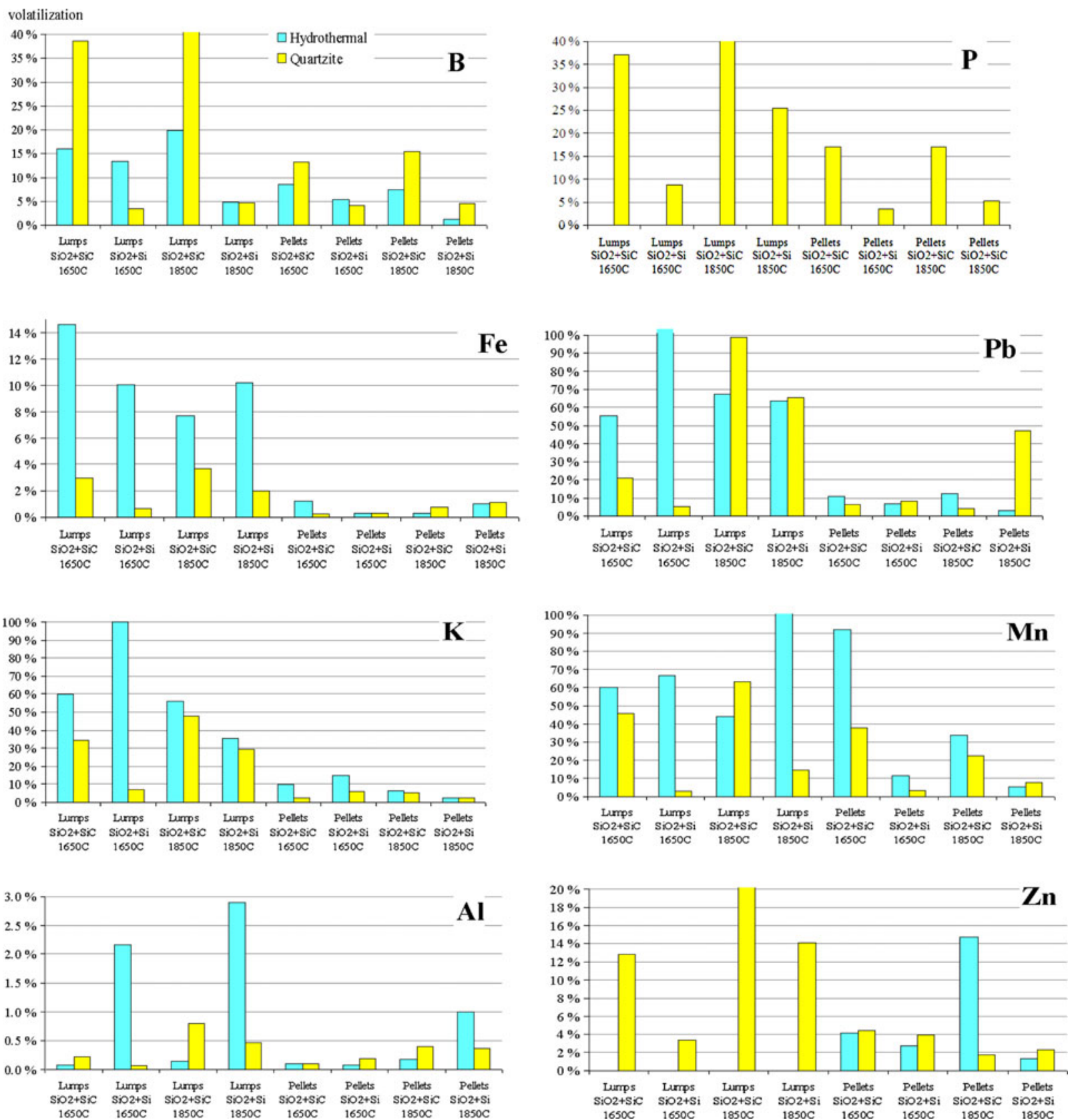

Fig. 6-Volatility of elements (mass pct) for different experimental conditions. Note the difference in volatility scale between the individual graphs.

$\mathrm{SiC}$, and $\mathrm{Si}$ were found in the condensate. The presence of crystalline $\alpha$-quartz may be due to the recrystallization of the amorphous silica during long-term exposure at relatively high temperatures in the tube.

The experiments stopped when the condensate derived from $\mathrm{SiO}(\mathrm{g})$ and $\mathrm{CO}(\mathrm{g})$ blocked the tube. Figure 3 shows that less time was required to block the tube when pellets rather than lumps were used. Since the condensate phase composition does not show a significant difference between experiments with lumps and pellets, it is possible to conclude that the rate of silica reduction is faster in pellets than in lump quartz. The property of pellets to produce more $\mathrm{SiO}(\mathrm{g})$ was stated by the same author in previous publication. ${ }^{[16]}$

\section{B. Impurity Volatility: Effect of Temperature and Charge Mix}

During the heating and reduction of quartz, impurities oxides in quartz were reduced to gaseous compounds that were collected in the condensate. The degree of volatilization is defined as the ability of the impurity, denoted $e l$, present in the quartz to report to the gas phase,

$$
\text { volatilization }=m_{e l, \text { gas phase }} / m_{e l, \text { charge mix }}
$$

where " $m_{e l \text {,charge mix }}$ " is the impurity content by mass in

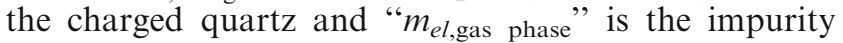
content by mass in the condensate. 


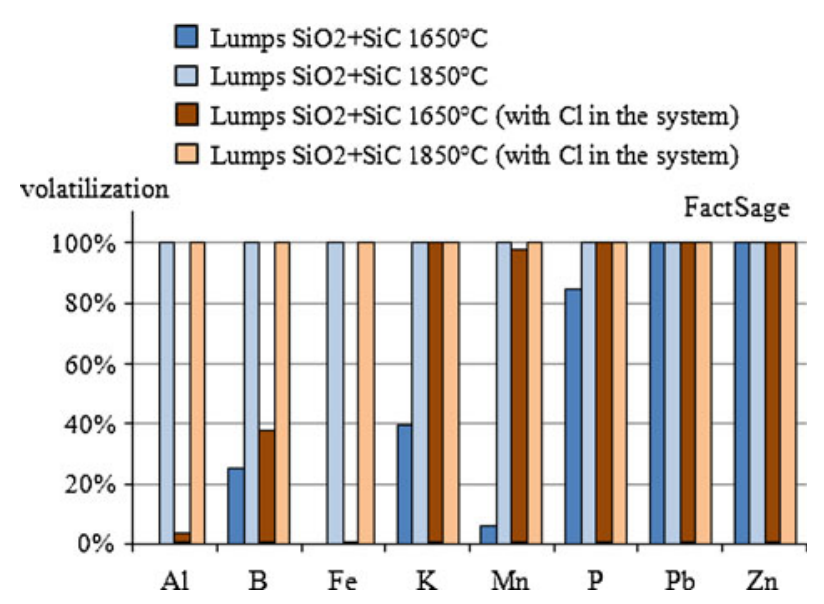

Fig. 7-Effect of chlorine on volatilization of impurities oxides in quartz during quartz reduction calculated using FactSage.

The impurity volatilization during quartz reduction was studied both experimentally and by thermodynamic simulations and summarized in Figure 4. The experimental results refer to quartzite and hydrothermal quartz, while thermodynamic analysis refers to a quartz material having the same impurity content as the quartzite used in the experiments. The experimental conditions with pellets were simulated adding the amount of carbon present in the binder.

Figure 5 shows the partial pressure of $\mathrm{SiO}$ and $\mathrm{CO}$ formed at equilibrium conditions, as calculated using FactSage. The atmosphere created during the experiments varies with the temperature and the charge mix. In general, by decreasing the temperature and by increasing the amount of free carbon (i.e., by using pellets instead of lumpy charge or by using the charge mix $\mathrm{SiO}_{2}+\mathrm{SiC}$ instead of $\mathrm{SiO}_{2}+\mathrm{Si}$ ), the equilibrium partial pressure of $\mathrm{SiO}\left(\mathrm{P}_{\mathrm{SiO}}\right)$ decreases in favor of $\mathrm{P}_{\mathrm{CO}}$. It should be mentioned that the experiments were carried out in argon, which was the main gas component in the reduction experiments $\left(\mathrm{P}_{\mathrm{CO}}+\mathrm{P}_{\mathrm{SiO}}<1\right)$.

Figure 4 shows that all the elements, which were found in the quartz charged, entered the gaseous phase. The volatility depends on the quartz type and the experimental conditions. The measured volatility of $\mathrm{B}$ for the experimental condition "quartzite-lumps $\mathrm{SiO}_{2}+\mathrm{SiC}$ $2123 \mathrm{~K}\left(1850^{\circ} \mathrm{C}\right)$ " was significantly higher than 100 pct, which is probably a result of an analytical error.

In general, oxides more stable than $\mathrm{SiO}_{2}$ remain in the mixed oxide/carbide/Si phase, while oxides less stable than $\mathrm{SiO}_{2}$ are expected to reduce to pure elements or suboxides during the reduction of quartz. If these reduced compounds have a high partial pressure, they will leave the quartz in form of gaseous compounds. Thermodynamic calculations volatilities depend on both the temperature and the charge mix: A higher volatilization is predicted at higher temperatures and higher $\mathrm{P}_{\mathrm{CO}}$.

The volatility of $\mathrm{Fe}, \mathrm{K}, \mathrm{Mn}$, and $\mathrm{Pb}$ for "lumps of hydrothermal quartz" lie on higher values than quartzite and pellets. Lumps of quartzite show a volatility profile similar to that thermodynamically predicted: higher volatility in correspondence of higher $\mathrm{P}_{\mathrm{CO}}$. Pellets of hydrothermal quartz and quartzite show a less pronounced dependence on $\mathrm{P}_{\mathrm{CO}}$. In general, the volatility of the elements in pellets is lower than in lumps.

Experimental results show that $\mathrm{Al}$ and Fe have very low volatilities regardless the temperature, the partial pressure of $\mathrm{CO}\left(\mathrm{P}_{\mathrm{CO}}\right)$, and the quartz used. The average volatility of $\mathrm{Al}$ and $\mathrm{Fe}$ is 1 pct and 4 pct, respectively. The low volatility of $\mathrm{Al}$ during quartz reduction is reflected in an increase in concentration of $\mathrm{Al}$ in quartz after reduction. This was confirmed in our previous article, ${ }^{[14]}$ which studied the impurities in quartz after reduction. Figure 4 shows that $\mathrm{Fe}$ is more volatile in lumps than in pellets. This behavior is particularly evident when hydrothermal quartz is used. This finding is in agreement with Part I, which studied the impurity content of quartz after reduction: Fe was more easily removed from lumpy quartz than from pellets charge, in particular when hydrothermal quartz was used. According to thermodynamic calculations, the main Fe- and Al-based gaseous compounds that form are $\mathrm{Al}(\mathrm{g})$ (b.p. $\left.2792 \mathrm{~K}\left[2519{ }^{\circ} \mathrm{C}\right]\right), \mathrm{Al}_{2} \mathrm{O}(\mathrm{g})$ (b.p. room temperature), and $\mathrm{Fe}(\mathrm{g})$ (b.p. $3134 \mathrm{~K}\left[2861{ }^{\circ} \mathrm{C}\right]$ ).

The average measured volatility for $\mathrm{K}$ is $26 \mathrm{pct}$. The two quartzes show the same trend when pellets are used [maximum volatility for the experimental condition "pellets $\mathrm{SiO}_{2}+\mathrm{Si} 1923 \mathrm{~K}\left(1650^{\circ} \mathrm{C}\right)$ )"] and a different trend when lumps are used. Quartzite lumps feature a volatility in agreement with the thermodynamic prediction. The main gaseous compound predicted by calculations is $\mathrm{K}(\mathrm{g})$ (b.p. $1032 \mathrm{~K}\left[759^{\circ} \mathrm{C}\right]$ ).

Experimental and thermodynamic results disagree on the behavior of $\mathrm{Zn}$ and $\mathrm{Pb}$. According to thermodynamic calculations, the volatility of $\mathrm{Zn}$ and $\mathrm{Pb}$ should be 100 pct $\mathrm{Zn}$ and $\mathrm{Pb}$ oxides are less stable than quartz and are easily reduced to $\mathrm{Zn}(\mathrm{g})$ (b.p. $1180 \mathrm{~K}\left[907^{\circ} \mathrm{C}\right]$ ) and $\mathrm{Pb}$ (g) (b.p. $2021 \mathrm{~K}\left[1748^{\circ} \mathrm{C}\right]$ ). However, experimental results show that the average volatility of $\mathrm{Zn}$ is only 10 pct and of $\mathrm{Pb} 36$ pct. A possible explanation for this behavior might be that $\mathrm{Zn}$ and $\mathrm{Pb}$ formed suboxides not predicted by the thermodynamic calculations.

The volatility of $\mathrm{Mn}, \mathrm{P}$, and B depends strongly on the charge mix: At high $\mathrm{P}_{\mathrm{CO}}$ pressure, corresponding to the charge mix " $\mathrm{SiO}_{2}+\mathrm{SiC}$," the volatility of $\mathrm{Mn}, \mathrm{P}$ and $\mathrm{B}$ increases. Mn, $\mathrm{P}$, and $\mathrm{B}$ are less stable oxides than quartz and are, hence, reduced to pure elements or suboxides having a relatively low boiling point. The main gaseous species that form according to thermodynamics are $\mathrm{P}(\mathrm{g})$ b.p. $553 \mathrm{~K}\left(280{ }^{\circ} \mathrm{C}\right), \mathrm{P}_{2}(\mathrm{~g}), \mathrm{PO}(\mathrm{g})$ b.p. room temperature, and $\mathrm{Mn}(\mathrm{g})$ b.p. $2335 \mathrm{~K}\left(2062^{\circ} \mathrm{C}\right)$. The average measured volatility of $\mathrm{Mn}, \mathrm{P}$, and $\mathrm{B}$ is 38 pct, 25 pct, and 11 pct, respectively.

Figure 4 shows that boron has lower volatility than Mn for all the experimental conditions, and the volatility is lower than $\mathrm{Pb}$ for most of the experimental conditions. B is generally less extracted from the charge than $\mathrm{Mn}$ and $\mathrm{Pb}$, the reason might be that $\mathrm{B}$ is a more stable oxide than $\mathrm{Pb}$ and $\mathrm{Mn}$ oxides or has lower diffusivity.

\section{Impurity Volatility: Effect of Fluid Inclusions}

Figure 6, as another way of presenting the results in Figure 4, shows the volatility of each element under 


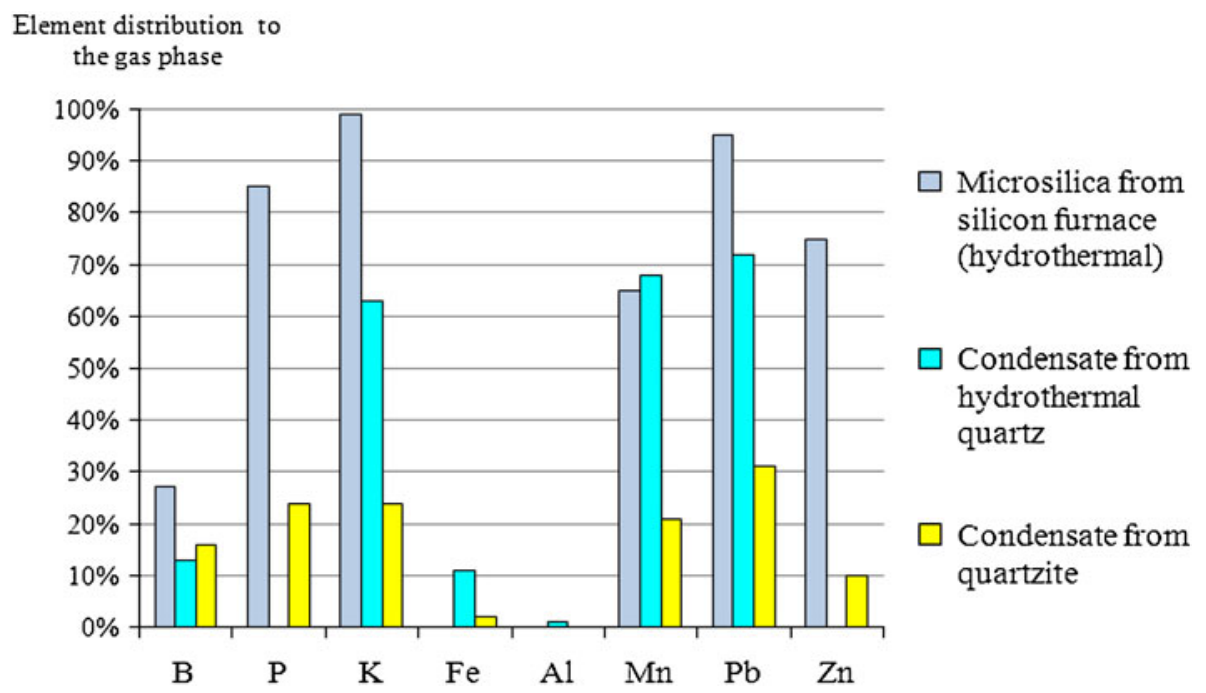

Fig. 8-Distribution of trace elements to microsilica from a Si furnace ${ }^{[2]}$ (light blue bars), compared to distribution of elements to the gas phase collected as condensate (dark blue bars when hydrothermal quartz was charged) in these experiments (dark yellow bars when quartzite was considered). Lumpy charge is here considered. All numbers are in we pct. Measurements in $\mathrm{Zn}$, Fe, and Al are partly available.

different experimental conditions and the quartz type (hydrothermal quartz in blue bars and quartzite in yellow bars).

Figure 6 shows that $\mathrm{Pb}, \mathrm{Fe}, \mathrm{Mn}$, and $\mathrm{K}$ have higher volatility in hydrothermal quartz than in quartzite when lumps are used. This trend can be attributed to fluid inclusions present in hydrothermal quartz. Fluid inclusions are only present in lumps of hydrothermal quartz; they are removed during quartz milling to the micrometers size in preparation of pellets. Fluid inclusions comprise water in solution with $\mathrm{Na}^{+}, \mathrm{K}^{+}, \mathrm{F}^{-}, \mathrm{Cl}^{-}, \mathrm{CO}_{2}$, $\mathrm{CH}_{4}$, and other contaminants. Fluid inclusions may have enhanced the volatilization by increasing the surface available to reduction of the quartz or by enhancing the formation of volatile Cl-based compounds.

During heating of quartz, the internal pressure of the fluid inclusions increases and they decrepitate; i.e., fissures run through the inclusions enabling removal of water vapor and $\mathrm{CO}_{2}$ from the inclusions. Decrepitation occurs from $473 \mathrm{~K}$ to $873 \mathrm{~K}\left(200{ }^{\circ} \mathrm{C}\right.$ to $\left.600{ }^{\circ} \mathrm{C}\right)$ depending on the fluid composition. Fluid inclusion decrepitation leaves cracks in quartz. ${ }^{[17]}$ The cracks increase the surface available to reduction, reduce the diffusion distance to the surface, and therefore increase the volatilization.

$\mathrm{Fe}, \mathrm{K}, \mathrm{Pb}$, and $\mathrm{Mn}$ in the quartz lattice or mineral impurities may react with $\mathrm{H}_{2} \mathrm{O}$ and $\mathrm{Cl}^{-}$ions in the fluid inclusions and form volatile compounds, which are subsequently liberated during reduction of the quartz. According to Larsen et al., ${ }^{[18]}$ elements like $\mathrm{Ca}, \mathrm{Fe}, \mathrm{Mg}$, and $\mathrm{Mn}$ are likely to be concentrated in submicroscopic fluid inclusions. The affinity of $\mathrm{Fe}$ with $\mathrm{Cl}^{-}$was studied in other works. ${ }^{[19]}$

FactSage equilibrium calculations also indicate that addition of $\mathrm{Cl}$ to quartz improves the evaporation of the impurities. Calculations with the addition of $100 \mathrm{ppmw}$ $\mathrm{Cl}$ to the system showed that main gaseous compounds formed are $\mathrm{AlCl}(\mathrm{g}), \mathrm{BCl}(\mathrm{g}), \mathrm{FeCl}_{2}(\mathrm{~g}), \mathrm{KCl}(\mathrm{g}), \mathrm{MnCl}_{2}(\mathrm{~g})$,
$\mathrm{PCl}(\mathrm{g}), \mathrm{PbCl}(\mathrm{g})$, and $\mathrm{ZnCl}_{2}(\mathrm{~g})$. The results of the thermodynamic calculations are shown in Figure 7. Two experimental conditions are studied: "lumps $\mathrm{SiO}_{2}+\mathrm{SiC} 1923 \mathrm{~K}\left(1650{ }^{\circ} \mathrm{C}\right)$ " and "lumps $\mathrm{SiO}_{2}+$ $\mathrm{SiC} 2123 \mathrm{~K}\left(1850^{\circ} \mathrm{C}\right)$." In both cases, the volatility increases in presence of $\mathrm{Cl}$.

\section{Impurity Volatility: Comparison with Industrial Measurements}

Myrhaug and Garcia ${ }^{[2,4]}$ studied the distribution of contaminants between a condensed phase (metal and slag), off-gases and microsilica for a $\mathrm{Fe}-\mathrm{Si}$ and a $\mathrm{Si}$ furnace.

Figure 8 compares the distribution of the impurities in the industrial arc furnace to microsilica (Myrhaug and Garcia $^{[2]}$ ) and to condensate in reduction of hydrothermal quartz and quartzite (this experimental work). Hydrothermal quartz was used for the $\mathrm{Si}$ industrial production.

In the industrial case, the condensation occurs between $1973 \mathrm{~K}$ and $1273 \mathrm{~K}\left(1700{ }^{\circ} \mathrm{C}\right.$ and $\left.1000{ }^{\circ} \mathrm{C}\right),{ }^{[8]}$ while in the experimental work discussed in this article, the condensate was produced down to far lower temperatures. Contrary to expectations, Figure 8 shows that the distribution of the elements to the condensate in these experiments is generally lower than the distribution of the elements to the microsilica in industrial experiments, although trends are the same. The difference in absolute numbers may be explained by different conditions in laboratory and industry experiments.

\section{CONCLUSIONS}

The major findings of this work are as follows:

- Carbothermal reduction of silica generates $\mathrm{CO}(\mathrm{g})$ and $\mathrm{SiO}(\mathrm{g})$ that form four types of condensate (based on 
color). The major constituents of the condensate phase are amorphous and crystalline $\mathrm{SiO}_{2}, \beta: \mathrm{SiC}$, and $\mathrm{Si}$.

- All the impurities that are present in the quartz charge enter the gas phase during quartz reduction to a varying degree.

- Al and Fe have a very low volatility in comparison with other elements.

- The average measured volatilities of $\mathrm{B}, \mathrm{P}, \mathrm{K}, \mathrm{Fe}, \mathrm{Al}$, $\mathrm{Mn}, \mathrm{Zn}$, and $\mathrm{Pb}$ determined experimentally are, respectively, $11 \mathrm{pct}, 25 \mathrm{pct}, 26 \mathrm{pct}, 4 \mathrm{pct}, 1 \mathrm{pct}$, 38 pct, 10 pct, and 36 pet.

- The volatility of Mn, P, and B depends on the charge mix: A higher $\mathrm{P}_{\mathrm{CO}}$ enhances the distribution of these elements to the gas phase.

- Liquid inclusions, common in hydrothermal quartz, enhance the distribution of the contaminants to the gas phase.

\section{ACKNOWLEDGMENTS}

The authors acknowledge John Sharp, Xing Xing, and Xiaohan Wan for their excellent technical help and productive discussions. This research work has been supported by ELKEM's research fund.

\section{REFERENCES}

1. E.H. Myrhaug: Non-Fossil Reduction Materials in the Silicon Process-Properties and Behaviour, NTNU, Trondheim, Norway, 2003.

2. M. Garcia and E.H. Myrhaug: Revisjon av Materialbalanse for Sporelementer i Si-ovn Basert på Målekampanje på Elkem Thamshavn April 2007, Elkem Silicon, Oslo, Norway, 2007.

3. H. Tveit and E. Myrhaug: Silicon for the Chemical Industry V, Tromsø, Norway, 2000, pp. 23-31.
4. E.H. Myrhaug and H. Tveit: Electric Furnace Conference Proceedings, American Institute of Mining and Metallurgical Engineers, New York, 2000, p. 58.

5. R.J. Ishak: Reaction Kinetics for Reduction of Manganese Ore with Carbon Monoxide in the Presence of Carbon, NTNU, Trondheim, Norway, 2002.

6. Y.E. Lee and D.S. Kozak: Electric Furnace Conference Proceedings, 1993, pp. 145-50.

7. J. Sterneland: Alkalis in the HCFeMn-Furnace, a Mass Balance of Potassium Oxide on the Furnace No 12 at Elkem Mangan a.s. $P E A$, Royal Institute of Technology, KTH, Stockholm, Sweden, 1993.

8. A. Schei, J.K. Tuset, and H. Tveit, eds.: Production of High Silicon Alloys, Tapir Forlag, Trondheim, Norway, 1998.

9. T. Førland and H. Flood, eds.: Selected Topics in High Temperature Chemistry. A Collection of Papers Dedicated to Professor Håkon Flood on His 60th Birthday, 25. Septemebr 1965, Universitetsforlaget, Oslo, Norway, 1966.

10. V. Andersen and M. Tangstad: Small Scale Laboratory Experiments Simulating an Industrial Silicon Furnace, in Infacon XII. Helsinki, Finland, 2010.

11. W. Poch and A. Dietzel: Ber. Dtsch. Keram. Ges., 1962, vol. 39, pp. 413-26.

12. A. Schei: Tidsskr. Kjemi Bergv, 1967, vol. 27, pp. 152-58.

13. J. Vangskåsen: Condensate Formation in the Silicon Process, NTNU, Department of Materials Science and Engineering, Internal Report, Trondheim, Norway, 2011.

14. E. Dal Martello, G. Tranell, O. Ostrovski, G. Zhang, O. Raaness, R.B. Larsen, K. Tang, and P. Koshy: Metall. Mater. Trans. B, 2012, in press.

15. A. Albinati and B.T.M. Willis: J. Appl. Cryst., 1982, vol. 15, pp. 361-74.

16. E. Dal Martello, G. Tranell, S. Gaal, O. Raaness, K. Tang, and L. Arnberg: Metall. Mater. Trans. B, 2011, vol. 42, pp. 939-50.

17. M. Gemeinert, M. Gaber, I. Hager, and M. Willfahrt: Neues Jahrbuch Miner. Abh., 1992, vol. 165, pp. 19-27.

18. R.B. Larsen, I. Henderson, and P.M. Ihlen: Contrib. Mineral. Petrol., 2004, vol. 147, pp. 615-28.

19. J.B. Fein, J.J. Hemley, W.M. D'Angelo, A. Komninou, and D.A. Sverjensky: Geochim. Cosmochim. Acta, 1992, vol. 56, pp. 3179-90. 